\title{
UNION PICKETING IN SHOPPING CENTERS
}

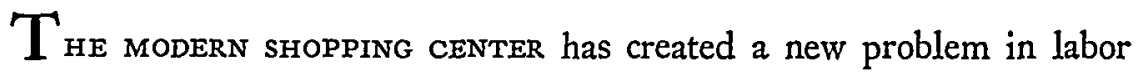
picketing. Shopping-center property does not usually belong to the picketed employer, and the landowner may not want picketers on his property. ${ }^{1}$ Thus, a vital question is raised: Can a union picket an employer-tenant on shopping center property despite the objection of the landowner? Heretofore, there have been no judicial decisions dealing specifically with this problem. ${ }^{2}$

${ }^{1}$ This is not always true. Some landowners have invited picketers on their property to prevent the union's picketing the entire shopping center. See Comment, ro STAN. L. REV. 694 (1958). Others have posted their property against picketers for various reasons.

${ }^{2}$ In recent years only three opinions have been rendered which even approach this potentially important area. Two of those cases dealt with picketing, and the third involved union membership solicitation.

In People v. Barisi, 23 L.R.R.M. 2 I9o (N.Y.C. Magis. Ct. I948), which in vital respects is analogous to the instant case, it was held that New York City's Pennsylvania Railroad Station was a quasi-public place, and that, therefore, the union's right to picket a leased space in the station lobby was protected by the constitutional right of freedom of 'speech.

In Nahas v. Retail Clerks Int'l Ass'n, 144 Cal. App. 2d 808, 301 P.2d 932 (1956), a California court held that an employer-tenant in a shopping center could not enjoin as trespass the peaceful picketing of his store because he did not own the land. By implication, this holding would seem to give the landowner the right to exclude picketers on a trespass theory because he owns the property. The court, however, refused to sanction an attempt by the landowner to confer on the employer-tenant, through the lease agreement, the power to exclude all trespassers in front of his store. It held that the picketers were not interfering with the shopping-center owner's enjoyment of the premises, and, hence, that he had no power to exclude them which he could confer on the employer-tenant. Three inferences might be drawn from this decision: (I) To exclude picketers from shopping-center property, one must have title to the property and must show that his enjoyment of the premises is being impaired by the picketing. The court in the instant case seems to draw this inference from the Nahas decision. State v. Williams, 44 L.R.R.M. 2357, 2360 (Baltimore, Md. City Crim. Ct. r 959). (2) The landowner can exclude picketers from shopping-center land because he owns the land, if his enjoyment of the land is impaired, but he cannot confer this right on a tenant as to the land not covered by the lease. See Comment, 10 STAN. L. REv. 694, 697 (1958). (3) The court contradicts itself concerning the landowner's rights as against picketers.

In Spohrer v. Cohen, 3 Misc. 2d 248, 149 N.Y.S.2d 493 (Sup. Ct. 1956), a New York court held that the landowner could exclude union organizers' soliciting union membership on the premises of a farmer's market. The authority of this decision is weakened, however, because it is not clear whether the defendants were bona fide union organizers.

The Supreme Court has said on several occasions that a union, under certain cir- 
In State v. Williams, ${ }^{3}$ a union organizer was arrested for the organizational picketing of a drugstore in a privately owned shopping center ${ }^{4}$ from which picketers had been expressly excluded by the landlord.5 The picketing was peaceful and orderly, and did not interfere with shoppers' entering and leaving the stores. The defendant refused to leave the premises and was subsequently convicted of violating two state trespass statutes. ${ }^{6}$ His conviction was reversed on appeal on the grounds that he had committed no act of trespass, and that the statutes prohibiting trespasses were inapplicable to the case because of the doctrine of preemption developed by the United States Supreme Court in labor cases. The court reasoned, first, that because shopping center property is quasipublic, not private, property, the defendant's right to freedom of speech under the first and fourteenth amendments ${ }^{7}$ protected his right to picket there. ${ }^{8}$

cumstances, can conduct organizational activity on the employer's land despite his objections. NLRB v. LeTourneau Co., 324 U.S. 793 (1945). Cf., NLRB v. Babcock \& Wilcox Co., 35 I U.S. I05 (1956); NLRB v. Stowe Spinning Co., 336 U.S. 226 (1949). The Court of Appeals for the Seventh Circuit has similarly held that union organizational activity could be conducted on a company-owned street frequented by the public despite a company rule prohibiting such activity. Marshall Field \& Co. v. NLRB, 200 F.2d 375 (7th Cir. 1953). However, the circumstances under which this activity was permitted need not detain us because these cases were concerned with union activity on the employer's property. Labor picketing in a shopping center, on the other hand, is concerned with union activity on the property of a third party who is uninvolved in the labor dispute. Hence, the relationship between the parties is different and calls for a new analysis in accommodating the rights of the respective parties-an analysis not found in these cases.

${ }^{3} 44$ L.R.R.M. 2357 (Baltimore, Md. Crim. Ct. 1959).

- The shopping center was located on a forty-six acre tract of land in northwest Baltimore and was occupied by more than 50 retailing establishments.

ENotices were posted at every entrance to the shopping center: "No solicitors, peddlers, picketers permitted on Mondawmin property without the consent of the owners. Those not securing such consent will be considered trespassers and will be prosecuted to the full extent of the law. Mondawmin Corp."

- "Trespass Upon Posted Property. It shall be unlawful for any person to enter or trespass on any property which is posted against trespassers in a conspicuous manner. Any person so doing shall be guilty of a misdemeanor ..." MD. ANN. CodE art. 27 $\S 576$ (r957).

"Wanton Trespass Upon Private Land. Any person or persons who shall enter upon or cross over the land, premises or private property of any persons or persons in this State after having been duly notified by the owner or his agent not to do so shall be deemed guilty of a misdemeanor ...." MD. ANN. CoDE art. $27 \$ 577$ (1957).

7 "Congress shall make no law ... abridging the freedom of speech . . . ." U.S. Consr. amend. I. "[N] $[\mathrm{N}$ or shall any State deprive any person of life, liberty, or property without due process of law. ..." U.S. ConsT. amend. XIV.

8 "Thus, because the private property involved here has been opened to the public, it has taken on the nature of a quasi-public place. By opening it to the public, the 
This decision comports with the principles of the leading case of Marsh v. Alabama, ${ }^{9}$ where the United States Supreme Court held that a member of Jehovah's Witnesses who distributed religious literature on the streets of a company-owned town was not guilty of a criminal trespass. The Court stated that, "The more an owner, for his own advantage, opens up his property for use by the public in general, the more do his rights become circumscribed by the statutory and constitutional rights of those who use it."10 Thus, under certain circumstances, a constitutionally protected activity may be conducted on property open to the public regardless of whether it is publicly or privately owned.11 Because labor picketing is a qualified right of free speech and a shopping center is a quasi-public place, it reasonably follows that unions have the right to picket in shopping centers.

The instant decision does not hold, however, that a trespass may never be committed on shopping-center property. In an apparent attempt to balance the right to freedom of speech and the rights of private property, the court held that no criminal trespass is committed on the premises of a shopping center except by "activities which would interfere with the purposes of the center or which may directly affect them in

owner's property rights have become secondary to broad use by the public, which includes the right of a labor union to engage in peaceful picketing." 44 L.R.R.M. at 2360 .

The Supreme Court has held that labor picketing is a right of free speech protected by the first and fourteenth amendments to the Constitution. Carlson v. California, 3 ro U.S. 106 (1940); Thornhill v. Alabama, 3 10 U.S. 88 (1940). Picketing enjoys constitutional protection if: ( $\mathrm{x}$ ) it is peaceful and orderly, Milk Wagon Drivers v. Meadowmoor Dairies, 312 U.S. 287 (1941); (2) it is confined to the physical area relevant to the labor dispute, Carpenters \& Jomers Union v. Ritter's Cafe, 3 15 U.S. 722 (1942), and (3) it does not contravene any valid state policy such as right-to-work legislation, anti-trust legislation, and protection of small business, United Ass'n of Journeymen Plumbers v. Graham, 345 U.S. 192 (r953); Building Serv. Employees Union v. Gassam, 339 U.S. 532 (1950); International Bhd. of Teamsters v. Hanke, 339 U.S. 470 (1950); Giboney v. Empire Storage \& Ice Co., 336 U.S. 490 (r949).

The decision has particular relevance in the field of civil rights for it holds that it is state action in the fourteenth amendment sense when ( 1 ) a publicly-visited shopping center exclndes people from its premises, and (2) the state enforces this exclusion through its trespass statutes. Similarly, it would appear to be state action under the fourteenth amendment when ( $x$ ) a publicly-visited shopping center excludes people on the basis of race, and (2) the state enforces this exclnsion by arresting such people for criminal trespass. Thus, the recent arrests of negroes for trespass in the Cameron Village Shopping Center, Raleigh, North Carolina, would seem to be state action under the instant decision.

326 U.S. 501 (r946).

${ }^{10} \mathrm{Id}$. at 506 .

${ }^{11}$ See also, People v. Barisi, 23 L.R.R.M. 2 r9o (N.Y.C. Magis. Ct. 1948). 
some way, be it monetary or otherwise."12 It then concluded that peaceful picketing does not interfere with the purposes of a shopping center.

This is specious reasoning, however, because picketing does interfere with the economic purposes of the shopping center by admonishing the public not to trade there. ${ }^{13}$ It would seem, therefore, that the real reason for permitting picketing on shopping-center premises, while excluding, for example, peddlers and solicitors as trespassers, is that picketing is protected as a qualified right of free speech, while the activities of a peddler or solicitor are not so protected.

The court thus made a sound policy choice between the rights of private property and individual liberty. It properly extended to unions the right to picket in privately-owned shopping centers, and thereby precluded what might have otherwise become an effective means of combatting unionism. A contrary decision would enable shoppingcenter merchants to harass retail trade unions by inducing their landlords to prohibit picketing on the premises. Because picketing is a prime union weapon in disputes with management, ${ }^{14}$ such collusion might severely hamper union activity. ${ }^{15}$ As the opinion points out, shoppingcenter merchants deserve no special immunity from union activity over merchants on public thoroughfares. ${ }^{16}$

The second ground of decision in the instant case, based on principles enunciated in San Diego Building Trades Council v. Garmon, ${ }^{17}$

\footnotetext{
${ }^{13} 44$ L.R.R.M. at 2359 .
}

${ }^{13}$ Indeed, the economic pressure may be so great that the owner of the shopping center will invite the picketers on his property to picket the employer with whom they have a labor dispute instead of picketing the entire shopping center on the public walks. Comment, Io STAN. L. REV. 694 (1958).

14 Smith, Labor Law 348 (I950).

${ }^{16}$ Perhaps the unions could retaliate by picketing the entrances to the shopping center, but the NLRB has yet to pass upon the legality of such picketing. $C f_{\text {., }}$ Retail Clerks, I 6 N.L.R.B. 856 (I956); Moore Dry Dock Co., 92 N.L.R.B. 547 (1950). Further, such picketing would seem unfair since it exerts economic pressure on the inerchant-tenants with whom the union has no labor dispute. Hence, the instant decision seems sound because it avoids injustice to unions as well as innocent shopping-center inerchants.

10 "When the interplay of forces in our free society is considered, it may be seen that a tenant in a shopping center deserves no special immunity from labor union activity over that of the tenant elsewhere." 44 L.R.R.M. at 2362 .

${ }^{17} 359$ U.S. 236 (1959). The Court reversed a California court's award of damages to an employer whose business was picketed for the purpose of forcing him to sign a union shop contract. The NLRB had refused to hear the case presumably because the amount of interstate commerce involved did not meet its jurisdictional requirements. The peaceful union activity was held to be federally protected under $\S 7$ of the Labor Manageinent Relations Act so that the state could not exercise its authority. 
is that the state is powerless to interfere with peaceful picketing activity because federal legislation has pre-empted the field. ${ }^{18}$ The trespass statutes were thus held to be inapplicable to regulate peaceful picketing of this employer, who was engaged in interstate commerce. In the Garmon case, the Supreme Court decided that peaceful picketing activity is protected by the Labor Management Relations Act and is not subject to state regulation, even under statutes of broad general application.

An Illinois court ${ }^{19}$ has recently assumed a position contrary to the instant case by holding that state trespass statutes are applicable to labor picketing, the Garmon decision notwithstanding, on the theory that "compelling state interests"20 may still be protected by the state. While the Supreme Court used such langauge in the Garmon case, it had reference only to maintaining the public peace. The Court's reservation was not intended to alter its basic holding that peaceful picketing may not be regulated by the states. ${ }^{21}$

Both facets of the Williams case are sound from the standpoint of public policy: Peaceful picketing in shopping centers should be permitted and should be regulated by the federal government when directed against firms dealing in interstate commerce. Thus, the court has fashioned a sound basis for the resolution of subsequent cases involving picketing in shopping centers.

${ }^{18}$ The court also relied on the case of Marshall Field \& Co. v. NLRB, 200 F.2d 375 (7th Cir. 1953), for the proposition that peaceful picketing in a quasi-public place is federally protected. However, the land involved in that case belonged to the $\mathrm{cm}$ ployer, not to a third party as in the instant decision. Nevertheless, the case does indicate that in one context picketing in a quasi-public place is federally protected.

${ }^{10}$ People v. Mazo, 28 U.S.L. WeEk 2126 (IIl. Cir. Ct. Sept. 29, 1959).

${ }^{20} \mathrm{Td}$. at 2127 .

${ }^{31}$ However, the Labor-Management Reporting and Disclosure Act of 1959 gives the state courts the power to enforce state laws in an otherwise pre-empted federal field if the Board has declined jurisdiction. The Board cannot decline jurisdiction over cases which it would hear under the standards prevailing on August 1, 1959. 44 L.R.R. at 433 . 